\title{
Assessment of Proper Capital Sufficiency of Regional Commercial Banks
}

\author{
Olga Vorozhbit
}

\author{
Tatyana Danilovskikh \\ Irina Kuzmicheva
}

\begin{abstract}
Vladivostok State University of Economics and Service, Russia, Vladivostok, Gogol st., 41 Email: Olga.Vorozhbit@vvsu.ru, Tatyana.Danilovskih@vvsu.ru,Irina.Kuzmicheva@vvsu.ru
\end{abstract}

\author{
Doi:10.5901/mjss.2015.v6n5s3p71
}

\begin{abstract}
Today the role of regional banks of medium size, which have several advantages over large multi-branch banks is increasing, this raises the need to analyze the stability of the regional banking system, at first to assess the adequacy of capital base of regional banks of medium and small size. The article discusses the concept of a regional bank, regional banking system, its institutional structure and level of development, a brief description of the banking system of subjects of the Far Eastern Federal district of the Russian Federation is given. The authors evaluated the adequacy of capital base of small regional banks focused on the needs of their region to determine the possible negative impact of requirements strengthening to the sufficiency from the side of the regulator. The study was conducted on the example of commercial banks registered in the Far Eastern Federal district of the Russian Federation. The calculation results indicate the absence of significant impact of Basel III requirements on capital adequacy in the regional banking system of the Far Eastern Federal district.
\end{abstract}

Keywords: bank capital adequacy, regional bank system, regional banks, methods of assessment of capital adequacy, Basel III.

\section{Introduction}

Today the main task of the banking sector of Russia is the long-term sustainability of the banking system. It is impossible to speak about the orientation of the banks to the needs of the real sector of the economy and increasing the confidence of customers without it.

The tendency of declining capital adequacy of the banking sector, showing the decrease in the stock of its strength, is related to the impact of the financial crisis, the requirements strengthening for capital adequacy of banks by regulatory and supervisory authorities, effect of sectoral economic sanctions against Russia and its position on the SouthEast of Ukraine and Crimea, imposed by the EU and the USA, as well as the response of Russia's embargo, all these in aggregate negatively affect on the banking system of the Russian Federation.

While the stock of financial stability at large financial institutions are supported by the state, a small, regional banks need to make more efforts to maintain a sufficient level of liquidity, solvency and capital level in the present external and internal environment (Mackevich and Kuzmicheva, 2015).

A big plus is that regional banks generally are more liquid and better capitalized in comparison with larger commercial banks that have greater economic and geographical extent of the country and abroad.

\section{Literature Review}

Certain researchers as well as the authors' groups in the sphere of science and education were engaged in study of the dynamics of a development vector of electronic works. So, for example, reviews of the results of a registration in Rospatent (2013) are periodically published in the magazine «Birzha Intellektualnoi Sobstvennosti», a number of the authors conduct a comparative analysis of the author's activity on the materials of Russia and Turkey (Fyodorov V. K. and Akylla Kh. (2015). A number of authors investigate development of a registration of the intellectual property in separate branches (Trifonov M.V. and Kuznetsova O. A., 2014; Bobkova E.Yu., 2015). Regular analytical reviews of a general character (Galkina A.I., Soshnikova E.A., Bobkova E.Yu., Grishan I.A. 2014; Galkina A.I., Bobkova E.Yu., Burnasheva E.A., Grishan I.A., Komarova M. V., 2014) and reviews devoted to the certain types and forms of electronic resources, and also their roles in the organizations' activity (Galkina A.I., 2014;) as well as scientific works devoted to the 
technology of a registration of electronic resources included in JFERSaE base, also JFERSaE employees publish (Galkin A.I., 2012). Problems and prospects of the legal protection of electronic resources created as office works both in organizations of a various form of ownership (Dobrynin by B.O, 2014) and in educational institutions (Solomonenko L.A., 2014) attract in recent years a great interest of Russian researchers that emphasizes the relevance of the research which results are presented in this work.

\section{Methodology}

In the research process the general scientific and special methods, which show the relationship of the theory of the bank's capital adequacy and its practical implementation on the example of regional banks in the Russian Far East, the methods of comparative analysis and synthesis, comparison, generalization, and statistical methods, economic and financial analysis were applied.

In order to assess the capital adequacy of the regional banking system the methodology proposed in works of Sorokina (2008), Didenko and Chernovalova (2012), Manuilenko (2012) was used. The calculations of capital base in the accounting of commercial banks in the Far Eastern Federal district of the Russian Federation presented on the website of the CBR were information base for the study.

\section{Main Part}

It is necessary to clearly understand the terminology of the investigated problem in order to conduct the study. The concept of a regional credit institution is not legislated, as well as there is no established definition, but researchers (Murychev, 2004; Rykova, 2011; Gurova, 2014) highlight a number of features of functioning of the bank that allow to assign it to the category of regional:

1. the territory is limited to one or more subjects of the Russian Federation,

2. the asset size of up to 10 billion rubles

3. clients are local small and medium enterprises,

4. share of credit portfolio is over $50 \%$, etc.

The role of regional banks is growing every year, because namely regional banks are more focused on servicing small and medium businesses, local budgets and budget enterprises, etc. Their strengths are trust relationships with customers, effective management, efficient decision making, established contacts in the region, offering a broad range of services taking into account the specifics of the region.

In the present study commercial banks registered on the territory of subjects of the Far Eastern Federal district are observed as regional banks of FEFD. As on 01 January 2015 on the territory of the FEFD there were 22 registered credit institutions, which in the presence of certain signs can be classified as regional. The greatest number of them are in the Primorsky region, that is OJSC JSCB "Primorye", JSC "Dalnevostochniy Bank", OJSC SCB of Primorye "Primsotsbank", PJSC CB "SUMMIT BANK", LLC Primterkombank, JSC "Dalta-Bank. In the Sakhalin region there are 5 credit institutions: "OOO Okhabank" the Bank "Iturup" (LLC), ZAO "Holmskkombank", CB "Dolinsk" (CJSC), JSC "Tikhookeanskiy Vneshtorgbank". 4 credit institutions are registered on the territory of the Republic of Sakha (Yakutia) - AB "Aldanzolotobank" JSC, JSC "Nerungribank". Kamchatskiy Territory is represented by the three credit organizations "Municipal Kamchatprofitbank" (CJSC), CJSC "Solid Bank", JSC "Kamchatkomagroprombank". On the Khabarovsk Territory and the Amur region two banks are registered - the Bank of the "Ussuri "(JSC), JSC "Royal Credit Bank" and PJSC CB "Vostochniy", "Asiatsko-Tikhookeanski Bank" (OJSC), respectively. In the Magadan region, the Jewish Autonomous region and the Chukotka Autonomous Okrug there are no credit institutions, the banking sector is represented by branches of banks from other regions.

The focus of the work of regional banks to the needs of "their" region, leads to a weak diversification of the loan portfolio. The small size of the bank's capital is a consequence of the narrow customer base, low level of income, high dependence on the state of the regional budget.

A comparison of the institutional characteristics of the regional banking system in the Far Eastern Federal district of the Russian Federation in 2011-2015 showed a decrease in the number of head of credit organizations and their branches (table 1). 
Table 1 - The number of operating credit institutions and their branches on the territory of the Far Eastern Federal district of the Russian Federation, units (CBR website)

\begin{tabular}{|c|c|c|c|c|}
\hline Date & $\begin{array}{c}\text { The number of credit } \\
\text { organizations in the region }\end{array}$ & $\begin{array}{c}\text { Sum } \\
\text { total }\end{array}$ & $\begin{array}{c}\text { Tredit institutions, the parent organization } \\
\text { of which is located in this region }\end{array}$ & $\begin{array}{c}\text { Credit institutions, the parent organization } \\
\text { of which is in another region }\end{array}$ \\
01.01 .2010 & 31 & 172 & 23 & 149 \\
01.01 .2011 & 27 & 147 & 12 & 135 \\
01.01 .2012 & 26 & 136 & 7 & 128 \\
01.01 .2013 & 23 & 121 & 7 & 89 \\
01.01 .2014 & 22 & 96 & 6 & 83 \\
01.01 .2015 & 22 & 89 & 714 \\
\hline
\end{tabular}

Moreover, in the regions the ratio of the number of local banks and branches of banks from other regions is constantly decreasing. Consequently, an ever-larger portion of the funding is concentrated at the Federal level, flowing from the regions, thereby defining a negative trend of decreasing level of competition in the banking sector, increasing dependence on the Federal government, the growth in the proportion of risk attributable to Federal banks.

At the same time, a number of such internal structural units of credit institutions is growing, as well as credit and cash and operating offices (table 2).

Table 2 - The number of internal structural units of credit institutions on the territory of the Far Eastern Federal district of the Russian Federation, units, (www.cbr.ru)

\begin{tabular}{|c|c|c|c|c|c|}
\hline Date & Additional offices & Cash offices out of cash operating unit & Lending and cash services office & Operational office & Sum total \\
01.01 .2010 & 1139 & 275 & 64 & 105 & 1583 \\
01.01 .2011 & 1125 & 265 & 69 & 125 & 1584 \\
01.01 .2012 & 1074 & 232 & 87 & 308 & 1701 \\
01.01 .2013 & 983 & 207 & 108 & 539 & 1837 \\
01.01 .2014 & 1040 & 137 & 111 & 622 & 1910 \\
01.01 .2015 & 1000 & 113 & 104 & 645 & 1862 \\
\hline
\end{tabular}

The increase in the number of internal structural divisions of banks is characteristic not only for the Far East, but also for Russia on the whole. The number of banks and branches is reducing, the number of indoor units is increasing. This is due to the optimization of the bank's divisions and caused, primarily, by the desire to reduce costs associated with maintenance of a full-fledged banking offices.

Quantitative characteristics of the regional banking system adequately characterizes the dynamics of the development of banks in the region, however, does not give information about the qualitative composition and the prospects of development of the banking system in the region. Especially does not show the perspective of the development of the regional banking system.

For a complete picture of the development and distribution of commercial banks within the region, it is necessary to calculate the bank's capital relative share to total assets of regional banks in FEFD.

It is obvious that the credit institution with the largest shares in the structure of the capital of banks of FEFD will be more competitive and more effective in relation to customers and shareholders.

Table 3 - The share of commercial bank assets of subject of the Federation to total assets of regional banks in the Far Eastern Federal district as of January 01, \% (calculated by authors on www.cbr.ru)

Subjects of FEFD
Amursk region
Kamchatka Territory
Primorski Territory
The Republic of Sakha (Yakutia)
Sakhalin region
Khabarovsk Territory
FEFD

\begin{tabular}{c|c}
2010 & 2011 \\
45,8 & 54,53 \\
6,32 & 4,94 \\
32,41 & 27,94 \\
7,74 & 5,8 \\
5,18 & 4,45 \\
2,54 & 2,28 \\
100 & 100 \\
\hline
\end{tabular}

\begin{tabular}{l|l}
2011 & \\
54,53 & \\
4,94 & \\
27,94 & \\
5,87 & \\
4,45 & \\
2,28 & \\
100 &
\end{tabular}

\begin{tabular}{c|c|c}
2012 & 2013 & 2014 \\
59,09 & 66,06 & 67,06 \\
4,32 & 3,57 & 4,06 \\
25,86 & 20,59 & 17,96 \\
5,53 & 5,23 & 5,83 \\
3,54 & 3,29 & 3,68 \\
1,66 & 1,26 & 1,4 \\
100 & 100 & 100 \\
\hline
\end{tabular}


Table 3 shows that about $80 \%$ of the assets of regional commercial banks are concentrated in banks registered in the territory of the Amur region and the Primorski Territory. Banks of the Amur region are increasing their positions, while Primorski territory gives them up. Nevertheless, this indicator does not let to make a conclusion about the quality of asset management or the adequacy of the resource base.

Researchers (Krivoshapova and Votinceva, 2012) indicate that regional banks are typically small and mediumsized by total assets banks, for which it is difficult to compete in scale of operations with branches of banks from other regions, that does not prevent them, however, to have the capital adequacy ratios higher than that of the country's leading banks with an extensive branch network.

The capital base of a commercial bank is a most important resource for business and is initially formed at the expense of the owners. Unlike contracted on the terms of repayment, promptness and payment of funds of clients and investors the capital base of the bank has an irrevocable character (Leonov, 2013).

The value of own funds of the bank, primarily is in maintaining sustainability. Also a number of functions (Leonov, 2013), which perform the bank's capital base are selected, namely: safety, operational, regulatory.

The amount of capital base of the bank determines the scope of its activities. However, the existence of different methods of evaluating the capital (Didenko and Chernovolov, 2012) leads to the fact that when using this or that technique the quantity and quality of the bank's equity will be different.

So, capital base, calculated in accordance with Bank of Russia requirements, will be called the regulative, because in structure of capital base are taken into account such items as, for example, a subordinated loan, reducing or increasing the capital base, while in the Bank's balance sheet these items are not taken into account. Essentially, the regulatory capital is the capital base of the bank, but designed with some additional adjustments that the regulator believes is right (Sorokina, 2008).

Unjustified overstatement of capital in the calculation leads to false information about the prosperous condition of the bank and thereby misleads investors, shareholders and the bank itself. The latter, on the basis of overvalued capital base expands its active operations, facing increased risks. On the contrary, if the method of determining the cost of capital leads to its artificially dumping, narrowing of the range of active operations and, consequently, reducing of income will be observed (Didenko and Chernovalov, 2012).

In addition to the analysis of absolute values and structure of capital base of the bank it is necessary to analyze its share in comparison with the value of assets and liabilities by calculating the adequacy.

The term "capital adequacy", in banking practice and theory is interpreted ambiguously (Didenko and Chernovolov, 2012). Capital adequacy ratio is defined as its ability to compensate for losses and to prevent bankruptcy. On the other hand, the adequacy reflects the stability of the bank, its reliability, the degree of dependence between the value of capital and the risk exposure of the bank.

The significance of the bank's capital base, for its own financial condition and stability of the Russian banking system in general, led to the introduction of regulation of its value and adequacy on behalf of the Central Bank of the Russian Federation. At the international level, the regulation of banks activities is carried out by the Basel Committee on banking supervision, which in 1988 adopted the first regulatory requirements for commercial banks, the so-called "Basel I". Regulatory requirements of the Basel agreements are implemented in practice supervision not only in member countries but also, on a voluntary basis, in other countries. On January 1, 2014 came into force the rules of "Basel III" (www.bis.org).

Russia has made commitments to implement these recommendations in the Russian practices of supervision. According to the Bank of Russia the entry requirements of Basel III in Russia will be phased (www.cbr.ru). After the full switch to methodology of the Basel III in regulatory purposes, commercial banks will calculate and provide to the Central Bank information about the three adequacy ratio of capital base $\mathrm{H} 1.0, \mathrm{H} 1.1, \mathrm{H} 1.2$.

In connection with toughening of requirements for the stock and quality of banks ' capital base, some experts are concerned that a large portion of regional banks will not be able to carry out these requirements and will be forced to undergo bank resolution. However, preliminary calculations of capital adequacy of commercial banks of the Far Eastern Federal district by the method of the Basel III showed the presence of the factor of safety and the ability to perform the requirements of the regulator (Danilovskikh and Makovskaya, 2014).

To analyze the stock and structure of capital base of regional commercial banks in the Far Eastern Federal district in constituent entities of the Federation, were calculated: the coefficient $\mathrm{K} 1$ is the share of fixed capital in the capital base (table 4), the ratio of the rate of growth of banks ' capital base (IC) and the rate of growth of their assets (A) (table 5), the coefficient K2 is the profit share in the structure of capital base (table 6).

Division of capital base of commercial banks on the primary and secondary is consequence of the different roles of the various sources of capital base to ensure its reliability (Manuilenko, 2012), from this follow the differences in these 
types of capital base adequacy ratio calculation.

Table 4 - Dynamics of K1 in FEFD in constituent entities of the Federation at January 01, \% (calculated by authors on www.cbr.ru)

\begin{tabular}{|l|c|c|c|c|c|c|}
\hline Subjects of FEFD & 2010 & 2011 & 2012 & 2013 & 2014 & 2015 \\
Amursk region & 62,82 & 54,04 & 67,98 & 69,44 & 68,13 & 65,08 \\
Kamchatka Territory & 90,77 & 86,89 & 81,57 & 80,17 & 80,14 & 86,90 \\
Primorski Territory & 74,40 & 67,40 & 60,37 & 65,79 & 69,42 & 69,01 \\
The Republic of Sakha (Yakutia) & 85,98 & 81,73 & 85,69 & 81,89 & 74,00 & 75,38 \\
Sakhalin region & 90,49 & 89,08 & 84,51 & 79,55 & 78,84 & 74,86 \\
Khabarovsk Territory & 59,87 & 57,74 & 60,41 & 54,09 & 51,86 & 50,00 \\
FEFD & 71,09 & 63,28 & 68,41 & 70,12 & 69,30 & 67,57 \\
\hline
\end{tabular}

The capital requirements strengthening according to the requirements of Basel III will relate mainly to additional capital, therefore it is necessary to consider the interrelationship between the primary and secondary capital of the regional banks of the Far Eastern Federal district. According to the researchers (Sorokina, 2008, Manuilenko, 2012) the basic capital must at least two times exceed the amount of the additional

From the given calculations (table 4) follows the logical conclusion that the smaller the bank is, the less ability it has to attract additional sources of funding, and as the Central Bank also establishes requirements for the creation of reserves for different types of expenses, so respectively by the values of these indicators it is possible to estimate the potential financial feasibility of any of the considered bank.

In average for regional banks of the Far Eastern Federal district the share of fixed capital is about $70 \%$, which positively characterizes the stability of the regional banking system. In general, during the period under review, the share of basic capital decreases, indicating the increase in the activities of commercial banks in the region, which allow banks to find additional sources of capital base. Tables 3 and 4 also revealed an inverse relationship between the scale of the Bank's activities and the share of basic capital.

Attention should be paid to the value of bank assets and the ratio of chain growth of capital base and total liabilities (assets) of regional banks

Table $\mathbf{5}$ - The rate of growth of capital base and assets of the commercial banks in the Far Eastern Federal district in the context of subjects of Federation of January 01, \% (calculated by authors on www.cbr.ru)

\begin{tabular}{|l|c|c|c|c|c|c|c|c|}
\hline \multirow{2}{*}{ Subjects of FEFD } & \multicolumn{2}{|c|}{2011 to 2010} & \multicolumn{2}{c|}{2012 to 2011} & \multicolumn{2}{c|}{2013 to 2012} & \multicolumn{2}{c|}{2014 to 2013} \\
Amursk region & IC & A & IC & A & IC & A & IC & A \\
Kamchatka Territory & 126,50 & 189,25 & 146,17 & 145,56 & 165,73 & 159,86 & 133,48 & 110,22 \\
Primorski Territory & 105,28 & 124,08 & 112,68 & 117,51 & 149,90 & 118,29 & 107,99 & 123,48 \\
The Republic of Sakha (Yakutia) & 112,24 & 137,02 & 124,92 & 124,32 & 116,7 & 113,87 & 106,67 & 94,70 \\
Sakhalin region & 116,90 & 120,41 & 119,78 & 126,67 & 155,50 & 135,28 & 118,78 & 121,05 \\
Khabarovsk Territory & 101,58 & 136,42 & 110,99 & 107,00 & 126,42 & 132,48 & 110,00 & 121,74 \\
FEFD & 106,98 & 142,46 & 127,78 & 98,00 & 121,04 & 108,53 & 105,49 & 120,13 \\
\hline
\end{tabular}

According to the data presented in table 5 and figure 1 it can be concluded that the excess growth of assets over the growth of capital base, leads to lowering of ratios of adequacy. 


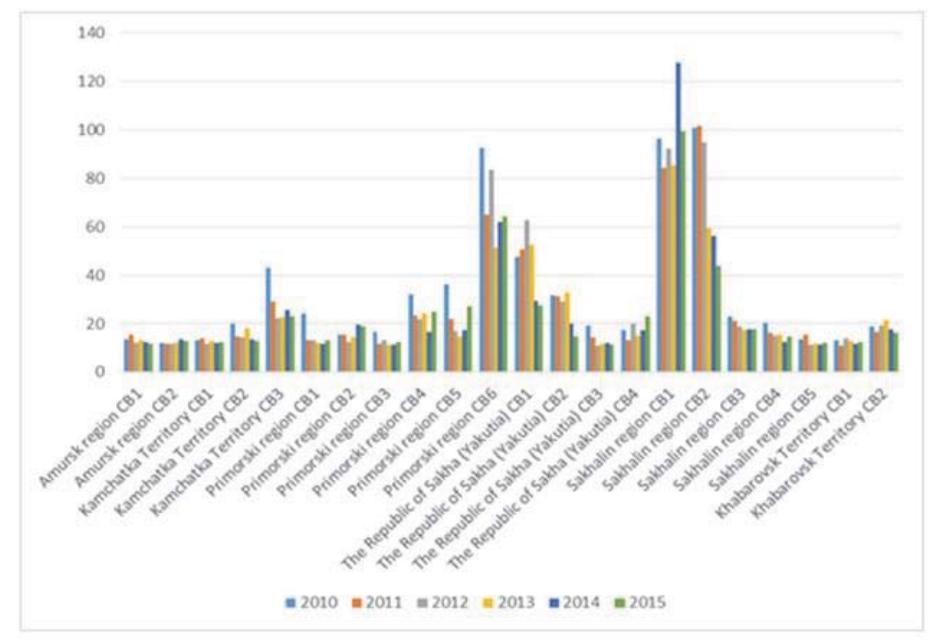

Figure 1 - The dynamics of the coefficient of capital adequacy

Over the last year adequacy ratio from the banks of the Primorski region, Sakhalin region grew, the value of the capital adequacy ratio $\mathrm{N} 1.0$ of commercial banks of other regions of FEFD slightly decreased.

Table 6 - The dynamics of the coefficient of the share of profit in capital base for commercial banks of FEFD have been given at January $01, \%$ (calculated by authors on www.cbr.ru)

\begin{tabular}{|l|c|c|c|c|c|c|}
\hline Subjects of FEFD & 2010 & 2011 & 2012 & 2013 & 2014 & 2015 \\
Amursk region & 90,75 & 91,6 & 93,7 & 95,8 & 96,8 & 96,1 \\
Kamchatka Territory & 71,43 & 71,83 & 78,10 & 77,63 & 79,10 & 80,02 \\
Primorski Territory & 59,00 & 60,40 & 61,97 & 62,38 & 62,83 & 65,12 \\
The Republic of Sakha (Yakutia) & 41,83 & 42,40 & 27,65 & 31,13 & 40,80 & 46,34 \\
Sakhalin region & 36,62 & 38,02 & 43,84 & 55,52 & 56,48 & 57,90 \\
Khabarovsk Territory & 62,55 & 64,55 & 67,25 & 64,75 & 67,30 & 66,78 \\
FEFD & 60,36 & 61,47 & 62,08 & 64,54 & 67,22 & 68,71 \\
\hline
\end{tabular}

The bank's capital can be replenished from two sources - internal (accumulated profits) and external (additional issue of shares) resources. More preferred is the former, because it is deprived of such a defect, as loss of control of bank management (Sorokina, 2008). The coefficient of share of profits in the bank's capital base can be calculated in different ways depending on the goals of the analysis. In our case it is calculated as the ratio of total capital base less authorized capital to the total value of capital base, i.e., the more earned or accumulated profits are, as well as other sources in capital base, the greater the value of this ratio will be.

The results of the element analysis of the sources of capital base of the regional banks in the Far Eastern Federal district showed that almost all banks use only one of options of compounding the capital base amount, it is profit. It should be noted that the growth rate of banks ' profits, as well as the opportunity to use other sources of formation of basic capital, are constraining, also because of the lack of long-term resources in the banking system (Vorozhbit and Terenteva, 2010). The emergence of such resources will increase the balance in money demand and supply, and thus increase the liquidity and stability of the banking system.

\section{Conclusion}

According to the results of the study we believe that the introduction of the requirements of "Basel III" for calculating norms of sufficiency of capital base of the bank, has not led to significant changes of the situation with capital adequacy in the regional banking system of the Far Eastern Federal district. 


\section{References}

Admati, A., \& Hellwig M. (2013). The bankers' new clothes: What's wrong with banking and what to do about it. Princeton: Princeton University Press.

Aiyar, S., Calomiris C., \& Wieladek T. (2014). Does Macro-Prudential Regulation Leak? Evidence from a UK Policy Experiment. Journal of Money, Credit and Banking, 46(1), 181-214.

Calomiris, C.W. (2013). Reforming Banks Without Destroying Their Productivity and Value. Journal of Applied Corporate Finance, 25(4), 14-20. doi: 10.1111/jacf.12037.

Danilovskikh, T.E. \& Makovskaya T.V. (2014). The capital adequacy ratio of commercial banks in the conditions of transition to the recommendations of the Basel-3: the regional dimension, Fundamental research, 8-3, 662-670.

Degryse, H., Elahi M., \& Penas M. (2012). Determinants of Banking System Fragility: A Regional Perspective, CEPR Discussion Paper 8858.

Didenko, Z.G. \& Chernovolov, S.S. (2012). Estimation of the magnitude and sufficiency of capital base of the bank. Economics and management, 6(80), 66-69.

Gurova, Ye.P. (2014). Stability of the regional banking systems in the crisis and post-crisis periods, Region's economy, 4, $237-245$.

Krivoshapova, S.V. \& Votinceva L.I. (2012). Improving oversight of the banking sector: regional features, the Asia-Pacific: Economics, politics, law, 1, 76-84.

Liu, H., Molyneux P. \& Wilson J. (2010). Competition and Stability in European Banking: A Regional Analysis. SSRN Electronic Journal.

Leonov, M.V. (2013). Features of formation and use of a capital base of commercial bank in Russia, Kazan economic Bulletin, 6(8), 6366.

Leonov, M.V. (2014). Features of regulation of capital base requirements for commercial banks in Russia. News of higher educational institutions. Series: Economics, Finance and production management, 1(19), 28-37.

Miles, D. (2013). Bank capital requirements: Are they costly? VOX, CEPR's Policy Portal. Retrieved May, 05, 2015, from http://www.voxeu.org/article/bank-capital-requirements-are-they-costly.

Miles, D., Yang J. \& Marcheggiano G. (2012). Optimal Bank Capital. The Economic Journal, 123(567), 1-37. DOI: 10.1111/j.14680297.2012.02521.x

Manuilenko V.V. (2012). The formation of the qualitative structure of the Bank's capital base. Banking, 12, 49-54.

Mackevich E.D. \& Kuzmicheva I.A. (2015) Risk of commercial bank, International journal of applied and fundamental research, 6-2, 313317.

Murichev, A.V. (2004). Regional banks in the system of financial intermediation. Banking, 9, 23-29.

Ratnovski, L. (2013). How much capital should banks have? VOX, CEPR's Policy Portal. Retrieved May, 05, 2015, from http://www. voxeu.org/article/how-much-capital-should-banks-have.

Rykova, I.N. (2011). Nature, types and main functions of regional banks Banking. 6. (URL:http://www.fa.ru//institutes/efo/science)

Sorokina, I.O. (2008). Methodological approaches to the analysis and evaluation of the bank's capital base by external users. Finance and credit, 47(335), 21-31.

The official site of the Basel Committee on banking supervision [Electronic resource]. - Access mode: http://www.bis.org/bcbs/index.htm (date of access: 15.04.2015)

The official website of the Bank of Russia [Electronic resource]. - Access mode: http://www.cbr.ru/credit/transparent.asp (date of access: 24.04.2015).

Voronin, D.V. (2012) Systemic risks in the banking sector of Russia: in the foreground the problem of capital adequacy. Banking, 2, 1315.

Vorozhbit, O.Y. \& Terenteva N.S. (2010) Identifying sources of long-term resources as the direction of increasing the liquidity of the banking system. Bulletin of the VSUES: Territory of new opportunities, 2, 116-133.

Votinceva, L.I. Financial strategy on a territorial basis: assessment, problems, prospects / L. I. Votinceva, etc. Vladivostok, Russia, pages 2008. 218. 